\title{
Abundance, biomass and energy use of native and alien breeding birds in Britain
}

\author{
Tim M. Blackburn (D) Kevin J. Gaston
}

Received: 1 February 2018/ Accepted: 4 July 2018/Published online: 11 July 2018

(C) The Author(s) 2018

\begin{abstract}
We quantify the contribution of alien species to the total breeding population numbers, biomass and energy use of an entire taxonomic assemblage at a large spatial scale, using data on British birds from 1997 and 2013. A total of 216 native and 16 alien bird species were recorded as breeding in Great Britain across the two census years. Only 2.8-3.7\% of British breeding bird individuals were alien, but alien species co-opted $11.9-13.8 \%$ of the energy used by the assemblage, and contributed $19.1-21.1 \%$ of assemblage biomass. Neither the
\end{abstract}

Electronic supplementary material The online version of this article (https://doi.org/10.1007/s10530-018-1795-z) contains supplementary material, which is available to authorized users.

\section{T. M. Blackburn $(\bowtie)$}

Department of Genetics, Evolution and Environment, Centre for Biodiversity and Environment Research,

University College London, Gower Street,

London WC1E 6BT, UK

e-mail: t.blackburn@ucl.ac.uk

T. M. Blackburn

Institute of Zoology, Zoological Society of London,

Regent's Park, London NW1 4RY, UK

\section{K. J. Gaston}

Environment and Sustainability Institute, University of Exeter, Penryn, Cornwall TR10 9FE, UK

\section{K. J. Gaston}

Wissenschaftskolleg zu Berlin, Institute for Advanced

Study, Wallotstrasse 19, 14193 Berlin, Germany population sizes nor biomasses of native and alien species differed, on average, in either census, but alien species biomass is higher than native species biomass for a given population size. Species richness underestimates the potential effects of alien bird species in Britain, which have disproportionately high overall biomass and population energy use. The main driver of these effects is the ring-necked pheasant (Phasianus colchicus), which comprised $74-81 \%$ of alien biomass, yet the breeding population of this species is still only a small fraction of the estimated 35 million birds released in the UK in autumn. The biomass of this release exceeds that of the entire breeding avifauna, and suggests that the pheasant should have an important role in structuring the communities in which it is embedded.

Keywords Alien - Biomass - Breeding birds · Energy use · Great Britain · Population size $\cdot$ Ringnecked pheasant

\section{Introduction}

Floras and faunas worldwide are increasingly colonised by alien species-those moved by human activities to areas beyond the natural biogeographic boundaries to their distributions (Blackburn et al. 2011). Established alien species accumulated at 
around eight first records (i.e. of an alien species in a geographic region) per year from 1500 to $1800 \mathrm{AD}$, but now average around one first record per day (Seebens et al. 2017). There is no evidence that the rate of alien species arrivals is slowing. For birds, more than three-quarters of dated introductions in the period 1500-2000 AD occurred in the twentieth century, and one quarter ( $>900$ introductions) in just the last 17 years of this century (Dyer et al. 2017).

Alien species are concerning for conservation biologists and environmental managers because they may exert negative impacts on native species, leading to population declines and even extinctions. For example, alien species are the primary cause associated with terrestrial vertebrate extinctions since 1500 $\mathrm{AD}$ (Bellard et al. 2016a), while more than a quarter of all extant bird species currently considered at high risk of extinction are threatened by alien species (Bellard et al. 2016b). Alien species contributing to extinction threats span a wide range of taxa, including mammals, birds, amphibians, insects and plants (IUCN 2017). However, most alien species have no recorded environmental impacts. For example, Evans et al. (2016) applied the new Environmental Impact Classification for Alien Taxa (EICAT) protocol (Blackburn et al. 2014; Hawkins et al. 2015) to categorise the impacts of 415 bird species with known alien populations. The recorded environmental impacts of most species were low (Minimal Concern or Minor in the EICAT scheme), although 37 species had impacts at a level that at least caused reduction in the population of a native species (Moderate or greater), in some cases driving native population extinctions. Nearly half of all recorded environmental impacts by birds were mediated via competition, with predation impacts ranked second in number (Evans et al. 2016). There was a complete absence of information on the impacts of more than $70 \%$ of alien bird species. These species may or may not be having detectable effects on native species, but in the absence of data it is impossible to say (Evans et al. 2016).

All animals require resources to grow, reproduce, and maintain viable populations, and all animals obtain resources by consuming other species. When this consumption is by an alien species, it may mean that food items become unavailable for use by native organisms, and is likely directly to affect populations of native species through herbivory, predation or parasitism. Conversely, alien populations may also provide novel food or other resources to the benefit of native species. Either way, it is likely that the presence of alien species has resource implications for native species, irrespective of whether these impacts have been studied and quantified. The magnitude of any such effects will depend on the per capita effect of each alien, and the number of alien individuals in the population (Parker et al. 1999). One way in which the overall impacts of alien species may be explored is therefore through a quantification of the contribution of alien species to the overall biomass and energy use of an assemblage, as (albeit imperfect) measures of the resource use of organisms in a biological assemblage. Here, we explore these relationships for the assemblage of British breeding birds. As far as we are aware, this is the first such analysis to be carried out at a national scale.

The British bird fauna is one of the best censused animal assemblages in the world, as a result of a large community of professional and amateur ornithologists contributing to citizen science surveys organised by UK statutory conservation agencies and non-governmental organisations. The resulting data have been used to inform the Avian Population Estimates Panel (APEP) in collating estimates of the size of breeding and (some) non-breeding populations of British birds (Stone et al. 1997; Baker et al. 2006; Musgrove et al. 2013). We combine APEP estimates of breeding bird numbers with data on species' body masses and energy use to assess the proportional contributions of native and alien species to the numbers of individuals, biomass and population energy use of the British avifauna. Our aim is to quantity the potential overall impact of alien species on the British countryside, in terms of their contributions to biomass and energy use, relative to that of the native species in the same taxon.

\section{Methods}

We based our analyses on the British breeding bird population size estimates published in the earliest (Stone et al. 1997) and most recent (Musgrove et al. 2013) APEP reports; we refer throughout to population estimates from 1997 and 2013, although the data underlying the estimates derive from different ranges of earlier years. From both of these reports, we used population size estimates referring to Great Britain only, or the arithmetic mean of the highest and lowest 
values where a range was indicated. APEP reports estimate population sizes using a variety of units (individuals, adult individuals, pairs, nests, territories, wild pairs, males, females). We converted all of these to number of individuals on the assumption that the number of individuals equals the number of adults, or twice the estimated number of pairs, territories, nests, males, females, or wild pairs. We ignored greater than or less than signs, and qualitative opinions on whether estimates were likely to be over- or underestimates. For the few species with breeding population size estimates of $0-1$ pairs, we assumed that there were two individuals in the assemblage. This makes a negligible difference to any of our statistics, given the overall size of the British breeding avifauna. Carrion and hooded crows (Corvus corone and Corvus cornix) and lesser and common redpolls (Carduelis cabaret and Carduelis flammea) were combined in the 1997 census but split in the 2013 one; for the sake of comparison, we recombined data from these species in the 2013 census.

We categorised bird species as alien if they are included on Category $\mathrm{C}$ of the official British Ornithologists' Union (BOU) list of British birds (BOU 2013); these are species that derive from introduced individuals but that now maintain selfsustaining populations. We considered Category C3 species (species with populations re-established by humans in areas of former occurrence) to be native, as these can technically be considered re-introduced rather than alien species. Population sizes of Category C species are reported by APEP (Stone et al. 1997; Musgrove et al. 2013). Category $C$ does not include all bird species with alien populations in Britain, as a dozen or so other alien bird species breed there in low numbers (Holling and The Rare Breeding Bird Panel 2017). These additional alien populations are not yet formally considered to be self-sustaining, and contribute only around 200 individuals to the British avifauna (Holling and The Rare Breeding Bird Panel 2017); we do not consider them further here. The native British avifauna comprises all breeding species on Category A of the official BOU list (BOU 2013). Some species include individuals of native and captive origin, most notably the greylag goose (Anser anser). We categorised such species on the basis of the origin of the majority of the breeding individuals in Britain. Thus, the greylag goose is considered alien in our analysis, although arguably it could be considered a native species with a breeding population enhanced by individuals deriving from captive ancestry.

APEP population estimates are presented with an estimate of reliability, from 1 (good) to 3 (poor). Musgrove et al. (2013) note that a score of 1 usually relates to estimates produced from direct counts with minimal extrapolation, 2 from extrapolation from reliable figures, and 3 from assumptions and expert opinion rather than actual fieldwork. They also note that reliability scores tend to be lower (i.e. confidence is higher) for population estimates of rarer species. We used these scores to compare the reliability of native versus alien population estimates, and to assess how reliability has changed between the two APEP reports.

We calculated the biomass of each species in the British breeding avifauna as the product of its population size estimate and an estimate of mean body mass. These body mass estimates are those presented in Appendix 3 of Gaston and Blackburn (2000), where sources are indicated. A handful of species have colonized Britain as breeding birds since this publication; body masses for these were obtained from Dunning (2013).

We calculated the population energy use of each species as the product of its population size estimate and an estimate of individual basal metabolic rate (BMR). BMR does not reflect the total amount of energy used by an individual across its lifetime as energy use will be higher when an individual is active. It nevertheless can be used to provide estimates of relative energy use across different species. BMR measurements are not available for most species, and so instead we estimated them from body mass (M) using the log-transformed version of the standard allometric equation $B M R=k M^{b}$ (see e.g. Peters 1983), such that $\log B M R=\log k+b \log M$. Kabat et al. (2008) showed that bird orders have common values of $b(0.73)$ but different values of $k$. Estimates of $k$ are not available for all bird orders in our analysis. However, an allometric model using different $k$ values for passerines and non-passerines is a better fit to BMR data than one assuming a common $k$ for all species $(\Delta \mathrm{AIC}=7.19$; Kabat et al. 2008) and we therefore used the values of $\log k$ for passerines $(-0.928)$ and non-passerines $(-1.085)$ calculated by Kabat et al. (2008). The units for BMR are $\mathrm{mlO}_{2} \mathrm{~min}^{-1}$.

We used paired $t$ tests to compare differences in log-transformed population size, biomass, and reliability scores between censuses. We added 1 to all 
values to account for breeding population sizes of zero in some censuses. We did not compare differences in population energy use because these were a constant function of biomass for each species. We used nonparametric Wilcoxon tests to compare the distributions of population size, biomass and population energy use between natives and aliens because the distributions of all these variables were highly leftskewed (skewness $=-0.45$ to -0.67 ), even when log-transformed. The samples size for native and alien categories were also very different (216 versus 16 species in total across both censuses). We used general linear models with Gaussian errors and identity link to compare alien and native species biomass when controlling for population size. We used a $\chi^{2}$ test to compare reliability scores between native and alien species in each census, calculating significance using a Monte Carlo simulation with 10,000 replicates to account for the fact that the sample sizes of alien reliability scores were low.

All statistical analysis was carried out in $\mathrm{R}$ (version 3.4.2) (R Core Team 2017), with skewness calculated using the moments package (Komsta and Novomestky 2015). The data used are given in Appendix S1 in the Supporting Information.

\section{Results}

The two APEP reports analysed include British breeding population estimates for 232 bird species, of which 216 are native and 16 are alien (Table 1). The commonest species in both reports is the wren (Troglodytes troglodytes), with a population estimate of 14.2 million individuals in 1997, and 15.4 million in 2013. The geometric mean ( \pm standard deviation) population size of native species in the 2013 census was $12,603 \pm 61$ individuals and for alien species $5633 \pm 55$ individuals. For 1997, these numbers were $12,184 \pm 55$ individuals for native species and $6135 \pm 18$ for alien. Population sizes were slightly higher, on average, in the second census (paired $\mathrm{t}=2.55, d f=212, P=0.012$ ). Population sizes in neither census differ on the basis of origin (Wilcoxon test, $1997: \mathrm{W}=1691, P=0.28 ; 2013: \mathrm{W}=1765.5$, $P=0.43)$.

The total number of individual breeding birds in 2013 was estimated to be $158,318,942$, of which $5,909,399$ were alien $(3.7 \%)$. The 2013 estimate of total population size was substantially higher than the 1997 estimate: in 1997, a total of 125,031,131 birds included 3,559,5703 alien individuals $(2.8 \%)$. The most abundant alien in both censuses was the ringnecked pheasant (Phasianus colchicus), with 3.1 million breeding birds estimated in 1997, and 4.4 million in 2013. These pheasants comprised $87 \%$ of all alien individuals in 1997, and 74\% in 2013.

The total biomass of all British breeding birds was estimated as 17,016 tonnes in 1997, and 23,964 tonnes in 2013. Alien biomass was 3257 tonnes in 1997, which was $19.1 \%$ of the total estimate. This had increased to 5057 tonnes $(21.1 \%)$ in 2013. Ringnecked pheasants again dominated the alien figures, with $80.8 \%$ (2635 tonnes) of the alien biomass attributable to this species in 1997, and $73.9 \%$ (3740 tonnes) in 2013. Indeed, the pheasant was the topranked species in the British avifauna in terms of biomass in 1997. It was displaced from this position in 2013 by the woodpigeon (Columba palumbus) with 5088 tonnes (21.2\% of the total), up from 2256 tonnes (13.3\% of the total) in 1997 . The geometric mean biomasses of native and alien species in the 1997 census were 1.35 and 5.61 tonnes, respectively, and 1.53 and 5.31 tonnes in 2013. Across species, biomass was higher on average in 2013 than 1997 (paired $\mathrm{t}=2.48, d f=212, P=0.014)$. The biomasses of native and alien species did not differ, on average, in either census (Wilcoxon test, 1997: $W=1250$, $P=0.41 ; 2013: \mathrm{W}=1320, P=0.30)$. However, alien species biomass is higher than native species biomass, when controlling for population size (e.g. in 2013: log population size (estimate \pm standard error) $=0.89 \pm$ $0.028, \mathrm{t}=32.41, P<0.0001$; origin (native relative to alien $)=-0.85 \pm 0.20, \mathrm{t}=-4.35, P<0.0001$; Fig. 1).

The geometric mean population energy use of native and alien species in the 1997 census was 232.5 and $472.5 \mathrm{mlO}_{2} \mathrm{~min}^{-1}$, respectively, and 255.3 and $441.9 \mathrm{mlO}_{2} \mathrm{~min}^{-1}$ in 2013 . The population energy use of native and alien species did not differ, on average, in either census (Wilcoxon test, 1997: $\mathrm{W}=1384$, $P=0.80 ; 2013$ : $\mathrm{W}=1470, P=0.67)$. The total population energy use by all British breeding birds was estimated as $2,227,175 \mathrm{mlO}_{2} \mathrm{~min}^{-1}$ in 1997 , and $3,049,637 \mathrm{mlO}_{2} \mathrm{~min}^{-1}$ in 2013. Alien individuals contributed $11.9 \%$ of the 1997 total, and $13.8 \%$ of the 2013 total. Once again, ring-necked pheasants dominated alien population energy use, with $85.0 \%$ of the 
Table 1 The list of British breeding bird species considered to be alien for the purposes of this analysis

\begin{tabular}{|c|c|c|c|c|c|c|c|c|c|}
\hline Family & $\begin{array}{l}\text { Common } \\
\text { name }\end{array}$ & $\begin{array}{l}\text { Scientific } \\
\text { name }\end{array}$ & EICAT & Mass & $\begin{array}{l}\text { Breeding } \\
\text { Pop. size } \\
1997\end{array}$ & $\begin{array}{l}\text { Breeding } \\
\text { Pop. size } \\
2013\end{array}$ & $\begin{array}{l}\text { Biomass } \\
1997\end{array}$ & $\begin{array}{l}\text { Biomass } \\
2013\end{array}$ & Diet \\
\hline Anatidae & Mute Swan & Cygnus olor & MN & 9700 & 25,750 & 12,000 & 249.775 & 116.400 & $\begin{array}{l}\text { Primarily aquatic } \\
\text { vegetation }\end{array}$ \\
\hline Anatidae & Snow Goose & $\begin{array}{l}\text { Chen } \\
\text { caerulescens }\end{array}$ & MN & 2631 & - & 8 & - & 0.021 & $\begin{array}{l}\text { Primarily plant } \\
\text { material, also seeds }\end{array}$ \\
\hline Anatidae & Greylag & Anser anser & DD & 3170 & 14,300 & 92,000 & 45.331 & 291.640 & $\begin{array}{l}\text { Primarily plant } \\
\text { material, also seeds }\end{array}$ \\
\hline Anatidae & $\begin{array}{l}\text { Canada } \\
\text { Goose }\end{array}$ & $\begin{array}{l}\text { Branta } \\
\quad \text { canadensis }\end{array}$ & MN & 3550 & 46,700 & 124,000 & 165.785 & 440.200 & $\begin{array}{l}\text { Primarily plant } \\
\text { material, also seeds }\end{array}$ \\
\hline Anatidae & $\begin{array}{l}\text { Barnacle } \\
\text { Goose }\end{array}$ & $\begin{array}{l}\text { Branta } \\
\quad \text { leucopsis }\end{array}$ & MN & 1702 & 730 & 1800 & 1.242 & 3.064 & $\begin{array}{l}\text { Primarily plant } \\
\text { material, also seeds }\end{array}$ \\
\hline Anatidae & $\begin{array}{l}\text { Egyptian } \\
\text { Goose }\end{array}$ & $\begin{array}{l}\text { Alopochen } \\
\text { aegyptiacus }\end{array}$ & MN & 2040 & 700 & 2200 & 1.428 & 4.488 & $\begin{array}{l}\text { Primarily plant } \\
\text { material, seeds and } \\
\text { some invertebrate } \\
\text { material }\end{array}$ \\
\hline Anatidae & Ruddy Duck & $\begin{array}{l}\text { Oxyura } \\
\text { jamaicensis }\end{array}$ & MO & 510 & 1140 & - & 0.581 & - & Invertebrates, seeds \\
\hline Anatidae & Mandarin & $\begin{array}{l}\text { Aix } \\
\quad \text { galericulata }\end{array}$ & MN & 512 & 7000 & 4600 & 3.584 & 2.355 & $\begin{array}{l}\text { Seeds, aquatic plants } \\
\text { and animals }\end{array}$ \\
\hline Anatidae & $\begin{array}{l}\text { Red-crested } \\
\text { Pochard }\end{array}$ & Netta rufina & DD & 967 & 100 & 31 & 0.097 & 0.030 & Plant material, seeds \\
\hline Phasianidae & $\begin{array}{l}\text { Ring-necked } \\
\text { Pheasant }\end{array}$ & $\begin{array}{l}\text { Phasianus } \\
\text { colchicus }\end{array}$ & MO & 850 & $3,100,000$ & $4,400,000$ & 2635.000 & 3740.000 & $\begin{array}{l}\text { Plant material, seeds } \\
\text { and some } \\
\text { invertebrates }\end{array}$ \\
\hline Phasianidae & $\begin{array}{l}\text { Lady } \\
\text { Amherst's } \\
\text { Pheasant }\end{array}$ & $\begin{array}{l}\text { Chrysolophus } \\
\text { amherstiae }\end{array}$ & DD & 714 & 150 & 10 & 0.107 & 0.007 & $\begin{array}{l}\text { Invertebrate and plant } \\
\text { material }\end{array}$ \\
\hline Phasianidae & $\begin{array}{l}\text { Golden } \\
\text { Pheasant }\end{array}$ & $\begin{array}{l}\text { Chrysolophus } \\
\text { pictus }\end{array}$ & MN & 607.5 & 1500 & 150 & 0.911 & 0.091 & $\begin{array}{l}\text { Primarily plant } \\
\text { material, some } \\
\text { invertebrates }\end{array}$ \\
\hline Phasianidae & $\begin{array}{c}\text { Red-legged } \\
\text { Partridge }\end{array}$ & Alectoris rufa & DD & 439 & 340,000 & 164,000 & 149.260 & 71.996 & $\begin{array}{l}\text { Plant material, seeds } \\
\text { and some } \\
\text { invertebrates }\end{array}$ \\
\hline Columbidae & $\begin{array}{l}\text { Rock Dove/ } \\
\text { Feral } \\
\text { Pigeon }\end{array}$ & Columba livia & MO & 355 & - & $1,080,000$ & - & 383.400 & Seeds, invertebrates \\
\hline Psittacidae & $\begin{array}{l}\text { Ring-necked } \\
\text { Parakeet }\end{array}$ & $\begin{array}{r}\text { Psittacula } \\
\text { krameri }\end{array}$ & MO & 92 & 3500 & 17,200 & 0.322 & 1.582 & $\begin{array}{l}\text { Fruits, seeds \& other } \\
\text { plant material }\end{array}$ \\
\hline Strigidae & Little Owl & Athene noctua & MO & 206 & 18,000 & 11,400 & 3.708 & 2.348 & $\begin{array}{l}\text { Invertebrate and } \\
\text { vertebrate prey }\end{array}$ \\
\hline
\end{tabular}

EICAT = impact classification under the Environmental Impact Classification Scheme for Alien Taxa (Blackburn et al. 2014; Evans et al. 2016); Mass = body mass (grammes); Breeding Pop. Size 1997 = Breeding Population Size estimated by Stone et al. (1997); Breeding Pop. Size 2013 = Breeding Population Size estimated by Musgrove et al. (2013); Biomass $1997=$ total biomass of the species in 1997 (the product of the Mass and Breeding Pop. Size 1997 columns); Biomass $2013=$ total biomass of the species in 2013 (the product of the Mass and Breeding Pop. Size 2013 columns)

1997 total and $76.5 \%$ of the 2013 total. The pheasant was the top-ranked species in the British avifauna in terms of population energy use in 1997, with the woodpigeon gaining top rank in 2013.
The 2013 census estimated the total British breeding population at $>33$ million more birds than the 1997 census (158.32 versus 125.03 million individuals). The 2013 total was thus a $26.6 \%$ increase over the 


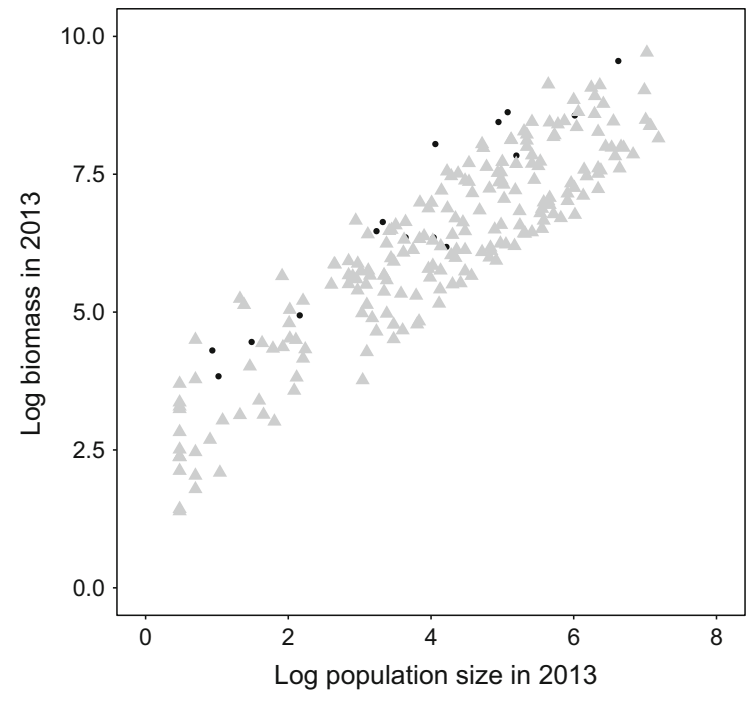

Fig. 1 The relationship between $\log _{10}$ biomass of a species in 2013, and its $\log _{10}$ population size estimate from that year. Black circles $=$ alien species; grey triangles $=$ native species

1997 value. Species with large increases between the two censuses include woodpigeon $(+5.9$ million birds), robin (Erithacus rubecula; +3.6 million), house sparrow (Passer domesticus; +3 million) and greenfinch (Chloris chloris; +2.34 million). The rock dove/feral pigeon (Columba livia) complex was not included in the 1997 figures and adds 1.08 million birds to the total. The estimate for breeding ringnecked pheasant numbers was 1.3 million higher in 2013 than 1997. The overall biomass increase between 1997 and 2013 was 6948 tonnes, or $40.8 \%$ of the 1997 total. The greatest contributions to this increase come from woodpigeon (2832 tonnes) and ring-necked pheasant (1105 tonnes).

Some of the difference in overall numbers may be accounted for by an increase in confidence in estimates over time. The mean reliability score declined significantly between censuses (2.06 in 1997 versus 1.84 in 2013; paired $\mathrm{t}=3.99, d f=212, P<0.001$ ), showing greater confidence in the more recent census numbers. This change was largely due to greater confidence in native population estimates. Native and alien population estimates did not differ significantly in reliability in the 1997 census (means of 2.06 vs 1.93, respectively; $\chi^{2}=5.4, P=0.06$ ), but native estimates were more reliable in the 2013 census (1.80 vs 2.40; $\left.\chi^{2}=16.1, P<0.0001\right)$. However, only two of the 14 bird species with population increases $>1$ million birds in the period between 1997 and 2013 showed increases in confidence in their population estimates in this period (house sparrow and European starling Sturnus vulgaris).

\section{Discussion}

The continued growth in the arrival and establishment of alien species (Seebens et al. 2017) is of concern because of their potential impacts on the environment and economy of the recipient regions (Vitousek et al. 1996). An increase in species numbers tells only part of the story, however. The impact of an alien population has been argued to depend on the size of the population, and the per capita effects of its individuals (Parker et al. 1999). If alien population sizes and per capita effects are generally small, then alien species richness may give an inflated view of the influence of these species in ecosystems. Certainly, the only current assessments of the environmental impacts of entire taxa of alien species suggests that impacts are mainly either small or unrecorded (Evans et al. 2016; Kumschick et al. 2017); impacts may be unrecorded because the species have negligible impacts that go unnoticed or are not worth studying (Evans et al. 2018). Conversely, alien species richness may underestimate the potential effects of these species if they have disproportionately high abundance or per capita impacts in an assemblage. This latter scenario seems to be the case in the British avifauna.

Using the criteria employed here, alien species comprise about $7.5 \%$ of the breeding species in the British avifauna. This figure may rise, with some of those that are not yet adjudged to have self-sustaining populations likely to attain these in the absence of control measures (e.g. black swan Cygnus atratus, muscovy duck Cairina moschata, monk parakeet Myiopsitta monachus; Holling and The Rare Breeding Bird Panel 2017) and attempts to eradicate alien species (e.g. ruddy duck Oxyura jamaicensis, monk parakeet) being unusual (Robertson et al. 2015; http:// www.nonnativespecies.org/index.cfm?pageid=294). Direct comparison between countries is difficult due to differences in the criteria by which species are considered to be alien and self-sustaining, but Britain is relatively rich in alien bird species and relatively poor in native species (c.f. Orme et al. 2005; Dyer et al. 2017). Britain is therefore probably towards the upper 
end of countries as ranked by relative alien bird species richness, although there are undoubtedly regions where this is much higher (e.g. Hawaii; Pyle and Pyle 2017). Nevertheless, alien species remain a relatively small proportion of the British breeding avifauna.

Alien bird species in Britain are not representative of the avifauna as a whole. There are no alien passerines established in Britain, yet $41 \%$ of native species are classified in this order. Conversely, $81 \%$ of alien British bird species are in the Galloanserae, compared with only $10 \%$ of natives. Britain has no alien seabirds or wading birds (Procellariformes, Pelecaniformes and Charadriformes), which comprise almost a quarter of the native breeding avifauna. The alien Anseriformes are primarily grazers of grassland or aquatic vegetation, but both these and the alien Galliformes also consume seeds, especially in winter. Invertebrates comprise a greater or lesser proportion of the diet of most alien Galliformes, as well as of the remaining alien species (Table 1). Alien bird species are on average roughly an order of magnitude largerbodied than native species (geometric mean mass: native species $=123 \mathrm{~g}$; alien species $=922 \mathrm{~g}$ ), and tend primarily to be herbivorous or omnivorous.

Large-bodied species are generally less abundant than small-bodied species (Brown 1995; Gaston and Blackburn 2000). As the alien bird species in Britain are generally large-bodied, we might expect that the proportional contribution of alien species to the numbers of breeding birds in Britain is smaller than their proportional contribution to species richness. This contribution is indeed small (only 2.8-3.7\%), such that the number of all breeding alien bird individuals is likely to be less than the uncertainty around the population estimates of the most abundant native breeding species. From this perspective, one might imagine that the environmental impact of alien species in this avifauna was likely to be small. However, a very high proportion of the alien bird population of Britain comprises individuals of largebodied species. The four commonest alien bird species in Britain are the feral pigeon, which averages around $350 \mathrm{~g}$, the red-legged partridge (Alectoris rufa; $440 \mathrm{~g})$, ring-necked pheasant (850 g) and Canada goose (Branta canadensis; $3500 \mathrm{~g}$ ), which contributed $97.6 \%$ of all alien bird individuals in 2013 (Table 1), and all of which are substantially heavier than the average native bird species. Given this disparity, considerations of biomass and energy use become particularly important. Indeed, alien species comprise a much higher proportion of the biomass (19.1-21.1\%) and energy use (11.9-13.8\%) of the breeding avifauna of Britain than they do of its species richness or overall population size. This suggests that these relatively few alien species are likely to have a disproportionate impact on the resources available to native species. For reference, the breeding biomass of alien birds in Britain in 2013 was higher than the biomass of Pelecaniformes and Charadriformes combined; that is, higher than the sum of all shorebirds (including oystercatchers, plovers, sandpipers, snipe, curlews), skuas, gulls, terns, auks, gannets, cormorants and shags. It was also equivalent to more than threequarters of the biomass of all British breeding passerines (including crows, larks, pipits, swallows, thrushes, tits, warblers, sparrows, finches, buntings), even though passerines comprised $84 \%$ of all the individual native breeding birds in Britain in 2013. For a given population size, alien species generally have relatively high biomass, and tend to lie along the upper margin of the relationship for native species (Fig. 1). At the species level, neither the population sizes nor biomasses of alien birds are exceptional, but their combination of these two variables is so.

By far the greatest contribution to the abundance, biomass and population energy use of alien bird species in Britain is made by the ring-necked pheasant. This species comprises 74 (2013)-87\% (1997) of all alien breeding individuals, 74 (2013)-81\% (1997) of the alien biomass, and 76.5 (2013)-85\% (1997) of alien population energy use. The ring-necked pheasant is relatively large-bodied, ranking in the top $20 \%$ of British breeding birds by body mass, as well as abundant, explaining its contribution to biomass. The lower energy use per unit body mass of such a largebodied species (Peters 1983) explains much of why the contribution of alien species to biomass is greater than to energy use. Nevertheless, in 1997, the alien pheasant population contributed more biomass, and used more energy, than any other species in the British breeding avifauna. It was only pushed into second place in 2013 in these metrics by the woodpigeon. Such dominance, particularly of biomass, of an assemblage by a single species would often be considered an indication of an important role in structuring that assemblage and of any wider community in which it was embedded (Gaston 2011). 
Breeding populations are of course only part of the picture when it comes to abundance, biomass and energy use of a natural assemblage. The British avifauna is supplemented through summer by successfully fledged immature birds, and in autumn and winter by immigrants from the continent. Many of the breeding individuals likewise depart for wintering quarters in continental Europe, Africa and elsewhere, while a proportion of the population of summering adult birds will comprise non-breeders. It is impossible to give good estimates of what the autumn and winter population sizes are for British birds, or the highest population size overall, because of the combined effects of the temporal dynamics of breeding output, juvenile mortality, the proportion of the resident population that does not breed, and the exchange of individuals with the continent. If we crudely assumed that most individuals of most species breed only once, that most populations are more or less stable (and hence that each breeding individual needs to produce a replacement bird), that influxes of winter birds are more or less equal to outflows of summer migrants, and that most birds in most populations are breeders, then the peak non-breeding population size might be double that of the breeding total. It seems likely that species coming in to winter are largerbodied on average than species breeding in Britain but wintering elsewhere, because wintering species will generally arrive from the north, while body mass tends to increase with latitude in the northern hemisphere (Olson et al. 2009), which may tend to increase wintering biomass more than wintering numbers. However, probably the largest change to the British avifauna outside of breeding individuals comes again from alien ring-necked pheasants, with the release of what is estimated to be around 35 million birds each autumn for shooting purposes (Bicknell et al. 2010). This adds almost 30,000 tonnes of pheasant biomass to the British avifauna, or roughly 1.5 times the entire 2013 native breeding bird biomass. If peak autumn/ winter native bird biomass was around double the breeding value, that would suggest around $780 \mathrm{~g}$ of pheasant for every kilogramme of native bird in the avifauna (see also Holling and The Rare Breeding Bird Panel 2017).

The potential consequences of so much pheasant biomass and energy use, both during and after the breeding season, on the resources available to native bird species are huge. The numbers alone suggest the likelihood of strong effects of direct competition on other seed and invertebrate consumers, as well as the likely effects of consumption on the plant and animal species being consumed. Areas of woodland with pheasant rearing pens and releases have different vegetation, invertebrate and bird population compositions to control areas, notably with reduced occurrence of large-bodied beetles at high pheasant release densities (Neumann et al. 2015), more individual warblers and woodpigeons (though not more species overall) and denser field layer vegetation (Draycott et al. 2008). Nearby hedges tend to be associated with more bare ground and weedy species and fewer perennial species and shrub and tree seedlings (Sage et al. 2009). Since pheasants are largely associated with farmland, their populations may especially add to the pressures on native farmland bird populations, which are currently in steep decline (Hayhow et al. 2017; but see Stoate 2002) due largely to the impacts of agricultural intensification (Donald et al. 2001). It would be useful to attempt to dissect the direct influence of pheasants on native animal and plant populations in general, given the wholesale changes and frequent declines in species' abundances and occupancy ongoing in the British countryside (Hayhow et al. 2016). Unfortunately, that will be difficult given the near ubiquity of pheasants across the British countryside (Balmer et al. 2013), and we are not aware of any studies that have attempted this.

In addition, pheasants may well increase the pressures on native bird (and other vertebrate) populations via apparent competition, both as a food source maintaining elevated populations of alien (e.g. Cole et al. 1995) and native (Gibbons et al. 2007) predators, and as a reservoir for shared parasite populations. In this last context, Tompkins et al. (2000) provided evidence that a nematode parasite shared between ring-necked pheasants and native grey partridges (Perdix perdix) could potentially be driving the large population declines seen in the latter species in the U.K., as the parasite is only maintained in the system in the presence of pheasant reservoir hosts (but see Potts 2010). This impact in particular led to classification of the ring-necked pheasant as MO (Moderate impact) using the recently developed EICAT scheme for classifying environmental impacts (Blackburn et al. 2014; Evans et al. 2016), as a result of evidence that the species contributed to population declines in at least one native species. 
With respect to predation, Turner and Sage (2003) estimated that $36 \%$ of released pheasants are predated or scavenged, principally by foxes (Vulpes vulpes). This potentially maintains relatively elevated predator populations that could depress native prey species below levels that would otherwise be expected. Indeed, there is evidence that populations of foxes, badgers (Meles meles), polecats (Mustela putorius), pine martens (Martes martes), American mink (Neovison vison) and grey squirrels (Sciurus carolinensis) have increased over the last few decades (Gibbons et al. 2007), and it has been suggested that this may in part be due to elevated gamebird numbers (Game Conservancy Trust 2004). However, environmental management associated with the gamebird industry could reverse any of these effects, at least locally, through supplemental feeding, habitat management or the control of predator populations. For example, Oldfield et al. (2003) showed that landowners who participate in gamebird shooting were more likely to maintain and plant woodland than landowners who do not participate, although these benefits did not extend to hedgerows. Likewise, Stoate (2002) found that declining passerine species benefitted from the introduction of a game management system on farmland. Whether the positive environmental and conservation benefits of pheasants and the industry that supports their British populations outweigh their negative impacts is an open question, and what is the overall impact of introductions of game species for field sports on biodiversity was one of 100 ecological questions of high policy relevance identified by Sutherland et al. (2006). It is likely to be particularly problematic to discriminate between the impacts of the pheasants themselves and the impacts of the management that they are frequently under.

By comparison with the pheasant, the environmental impacts of other alien bird species in Britain are undoubtedly much more limited. However, this is not to say that these impacts are non-existent. The ruddy duck, feral pigeon, ring-necked parakeet (Psittacula krameri) and little owl (Athene noctua) were all classified alongside ring-necked pheasant as having Moderate (MO), and therefore population-level, impacts on native species by Evans et al. (2016) in their recent global assessment. However, these classifications were all on the basis of effects documented outside the UK: the impact of ruddy ducks through hybridization with the threatened white-headed duck
(Oxyura leucocephala) in Spain (Robertson et al. 2015), of little owls through predation on insect populations in New Zealand (Watt 1979), of feral pigeons by disease transmission to Galápagos doves (Zenaida galapaagoensis) (Wikelski et al. 2004), and of ring-necked parakeets through nest site competition with nuthatches (Sitta europaea) in Belgium (Strubbe et al. 2010). The last of these species certainly has the potential for impacts on cavity-nesting birds in Britain, and while there is not yet good evidence for such an effect (Newson et al. 2011), the rapid population growth of this species (see Table 1) surely makes one more likely. The impacts of other alien bird species with populations in Britain are currently classified as Minor (MN), or in some cases even Data Deficient (DD) (Table 1). Most of these species currently have small enough populations that the product of per capita impacts and population size (Parker et al. 1999) is likely to be small. Whether it remains so into the future is of course unknown, while the best opportunity to prevent any such impacts is when such populations are small. The existence of impacts outside the U.K. has motivated ongoing attempts to eradicate the British ruddy duck and monk parakeet populations, although in the latter case it is largely economic impacts that are of concern (https://www.gov.uk/government/ publications/monk-parakeets).

In sum, the relatively small percentage of species in the breeding avifauna of Britain that is comprised of aliens belies their potential ecological significance, with fewer than $4 \%$ of bird individuals but around $20 \%$ of bird biomass attributable to alien species. However, despite the presence of high profile aliens such as ringnecked parakeets and Canada geese, the great majority of the individuals and biomass belong to the ringnecked pheasant, which is one of the most dominant components of the British avifauna. This dominance is yet further amplified by the annual introduction in the countryside of an additional population of pheasants that exceeds the biomass of the entirety of the breeding avifauna, and may plausibly be equivalent to perhaps three-quarters of peak native bird biomass. A proportion of this released population is shot over winter (the season runs from 1 October to 1 February), but a high proportion evidently is not: according to the Game and Wildlife Conservation Trust's National Gamebag Census, only around $40 \%$ of released pheasants are subsequently shot (Aebischer 2003), such that more than 20 million pheasants simply disappear into the 
British countryside. These birds may contribute to the apparently ongoing growth in pheasant breeding numbers, assuming that this population increase is real and not just a consequence of better population estimates in recent years. Such a weight of numbers suggests that the pheasant must have an important role in structuring the communities in which it is embedded. Yet, the distinct lack of evidence for either resource or apparent competition between pheasants and other bird species sits at odds with the massive population energy use of this species, and its equally large standing biomass relative to the native British avifauna. Its potential impact on the sizes of native breeding bird populations are obvious, yet we lack a rigorous analysis of the costs and benefits of flooding the countryside with alien birds, or of managing it for them (Lees et al. 2013).

Acknowledgements We thank two anonymous referees for comments that improved this manuscript. This represents the hundredth publication co-authored by T.M.B. and K.J.G. We thank Richard Gregory and Des McKenzie for assistance in obtaining literature.

Open Access This article is distributed under the terms of the Creative Commons Attribution 4.0 International License (http:// creativecommons.org/licenses/by/4.0/), which permits unrestricted use, distribution, and reproduction in any medium, provided you give appropriate credit to the original author(s) and the source, provide a link to the Creative Commons license, and indicate if changes were made.

\section{References}

Aebischer NJ (2003) The national game bag census. In: Miles S (ed) The game conservancy trust review of 2002. The Game Conservancy Trust, Fordingbridge, pp 61-65

Baker H, Stroud DA, Aebischer NJ et al (2006) Population estimates of birds in Great Britain and the United Kingdom. Brit Birds 99:25-44

Balmer DE, Gillings S, Caffrey BJ, Downie IS, Fuller RJ (2013) Bird Atlas 2007-11: the breeding and wintering birds of Britain and Ireland. BTO Books, Thetford

Bellard C, Cassey P, Blackburn TM (2016a) Biology of extinction: alien species as a driver of recent extinctions. Biol Lett 12:20150822

Bellard C, Genovesi P, Jeschke JM (2016b) Global patterns in threats to vertebrates by biological invasions. Proc R Soc Lond B 283:20152454

Bicknell J, Smart J, Hoccom D, Amar A, Evans A, Walton P, Knott J (2010) Impacts of non-native gamebird release in the UK: a review. RSPB Research Report Number 40
Blackburn TM, Pyšek P, Bacher S et al (2011) A proposed unified framework for biological invasions. Trends Ecol Evol 26:333-339

Blackburn TM, Essl F, Evans T et al (2014) A unified classification of alien species based on the magnitude of their environmental impacts. PLoS Biol 12:e1001850

British Ornithologists' Union (BOU) (2013) The British list: a checklist of birds of Britain, 8th edn. Ibis 155:635-676

Brown JH (1995) Macroecology. University of Chicago Press, Chicago

Cole FR, Loope LL, Medeiros AC, Raikes JA, Cynthia S (1995) Conservation implications of introduced game birds in high-elevation Hawaiian shrubland. Conserv Biol 9:306-313

Donald PF, Green RE, Heath MF (2001) Agricultural intensification and the collapse of Europe's farmland bird populations. Proc R Soc Lond B 268:25-29

Draycott RAH, Hoodless AN, Sage RB (2008) Effects of pheasant management on vegetation and birds in lowland woodlands. J Appl Ecol 45:334-341

Dunning JB (2013) Updates to the second edition of the CRC handbook of avian body masses: https://ag.purdue.edu/fnr/ Documents/BodyMassesBirds.pdf

Dyer EE, Cassey P, Redding DW et al (2017) The global distribution and drivers of alien bird species richness. PLoS Biol 15:e2000942

Evans T, Kumschick S, Blackburn TM (2016) Application of the environmental impact classification for alien taxa (EICAT) to a global assessment of alien bird impacts. Divers Distrib 22:919-931

Evans T, Pigot A, Kumschick S, Sekerçioglu CH, Blackburn TM (2018) Determinants of data deficiency in the impacts of alien bird species. Ecography. https://doi.org/10.1111/ ecog.03232

Game Conservancy Trust (2004) Review of 2003. Game Conservancy Trust, Fordingbridge

Gaston KJ (2011) Common ecology. Bioscience 61:354-362

Gaston KJ, Blackburn TM (2000) Pattern and process in macroecology. Blackwell Science, Oxford

Gibbons DW, Amar A, Anderson GQA, et al (2007) The predation of wild birds in the UK: a review of its conservation impact and management. RSPB research report no 23. RSPB, Sandy, UK

Hawkins CL, Bacher S, Essl F et al (2015) Framework and guidelines for implementing the proposed IUCN Environmental Impact Classification for Alien Taxa (EICAT). Divers Distrib 21:1360-1363

Hayhow DB, Burns F, Eaton MA, et al (2016) State of Nature 2016. The State of Nature partnership

Hayhow DB, Ausden MA, Bradbury RB, et al (2017) The state of the UK's birds 2017. The RSPB, BTO, WWT, DAERA, JNCC, NE and NRW, Sandy, Bedfordshire

Holling M, The Rare Breeding Bird Panel (2017) Non-native breeding birds in the UK, 2012-14. Brit Birds 109:92-108

IUCN (2017) The IUCN red list of threatened species. Version 2017-2. http://www.iucnredlist.org

Kabat AP, Blackburn TM, McKechnie AE, Butler PJ (2008) Phylogenetic analysis of the allometric scaling of therapeutic regimes for birds. J Zool 275:359-367 
Komsta L, Novomestky F (2015) moments: moments, cumulants, skewness, kurtosis and related tests. R package version 0.14. https://CRAN.R-project.org/package=moments

Kumschick S, Measey GJ, Vimercati G et al (2017) How repeatable is the Environmental Impact Classification of Alien Taxa (EICAT)? Comparing two independent global impact assessments of amphibians. Ecol Evol 7:2661-2670

Lees AC, Newton I, Balmford A (2013) Pheasants, buzzards, and trophic cascades. Conserv Lett 6:141-144

Musgrove AJ, Aebischer NJ, Eaton MA et al (2013) Population estimates of birds in Great Britain and the United Kingdom. Brit Birds 106:64-100

Neumann JL, Holloway GJ, Sage RB, Hoodless AN (2015) Releasing of pheasants for shooting in the UK alters woodland invertebrate communities. Biol Conserv 191:50-59

Newson SE, Johnston A, Parrott D, Leech DI (2011) Evaluating the population-level impact of an invasive species, Ringnecked Parakeet Psittacula krameri, on native avifauna. Ibis 153:509-516

Oldfield TEE, Smith RJ, Harrop SR, Leader-Williams N (2003) Field sports and conservation in the United Kingdom. Nature 423:531-533

Olson V, Davies RG, Orm CDL et al (2009) Global biogeography and ecology of body size in birds. Ecol Lett 12:249-259

Orme CDL, Davies RG, Burgess M et al (2005) Global hotspots of species richness are not congruent with endemism or threat. Nature 436:1016-1019

Parker IM, Simberloff D, Lonsdale WM et al (1999) Impact: towards a framework for understanding the ecological effects of invaders. Biol Invasions 1:3-19

Peters RH (1983) The ecological implications of body size. Cambridge University Press, Cambridge

Potts GR (2010) Pheasants, parasites and partridges. Brit Birds 103:123

Pyle RL, Pyle P (2017) The Birds of the Hawaiian islands: occurrence, history, distribution, and status. B.P. Bishop Museum, Honolulu, HI, USA. Version 2 (1 January 2017) http://hbs.bishopmuseum.org/birds/rlp-monograp
R Core Team (2017) R: a language and environment for statistical computing. R Foundation for Statistical Computing. Vienna, Austria. https://www.R-project.org/

Robertson PA, Adriaens T, Caizergues A et al (2015) Towards the European eradication of the North American ruddy duck. Biol Invasions 17:9-12

Sage RB, Woodburn MIA, Draycott RAH, Hoodless AN, Clarke $S$ (2009) The flora and structure of farmland hedges and hedgebanks near to pheasant release pens compared with other hedges. Biol Conserv 142:1362-1369

Seebens H, Blackburn TM, Dyer EE et al (2017) No saturation of the accumulation of alien species worldwide. Nat Commun 8:14435

Stoate C (2002) Multifunctional use of a natural resource on farmland: wild pheasant (Phasianus colchicus) management and the conservation of farmland passerines. Biodivers Conserv 11:561-573

Stone BH, Sears J, Cranswick PA et al (1997) Population estimates of birds in Britain and in the United Kingdom. Brit Birds 90:1-22

Strubbe D, Matthysen E, Graham CH (2010) Assessing the potential impact of invasive ring-necked parakeets Psittacula krameri on native nuthatches Sitta europeae in Belgium. J Appl Ecol 47:549-557

Sutherland WJ, Armstrong-Brown S, Armsworth PR et al (2006) The identification of 100 ecological questions of high policy relevance in the UK. J Appl Ecol 43:617-627

Tompkins DM, Greenman JV, Robertson PA, Hudson PJ (2000) The role of shared parasites in the exclusion of wildlife hosts: Heterakis gallinarum in the ring-necked pheasant and the grey partridge. J Anim Ecol 69:829-840

Turner C, Sage R (2003) Fate of released pheasants. Game Conservancy Trust Rev 35:74-75

Vitousek PM, D'Antonio CM, Loope LL, Westbrooks R (1996) Biological invasions as global environmental change. Am Sci 84:468-478

Watt JC (1979) Conservation of the Cromwell chafer Prodontria lewisi (Coleoptera: Scarabaeidae). N Z J Ecol 2:22-29

Wikelski M, Foufopoulos J, Vargas H, Snell H (2004) Galápagos birds and diseases: invasive pathogens as threats for island species. Ecol Soc 9(1):5 